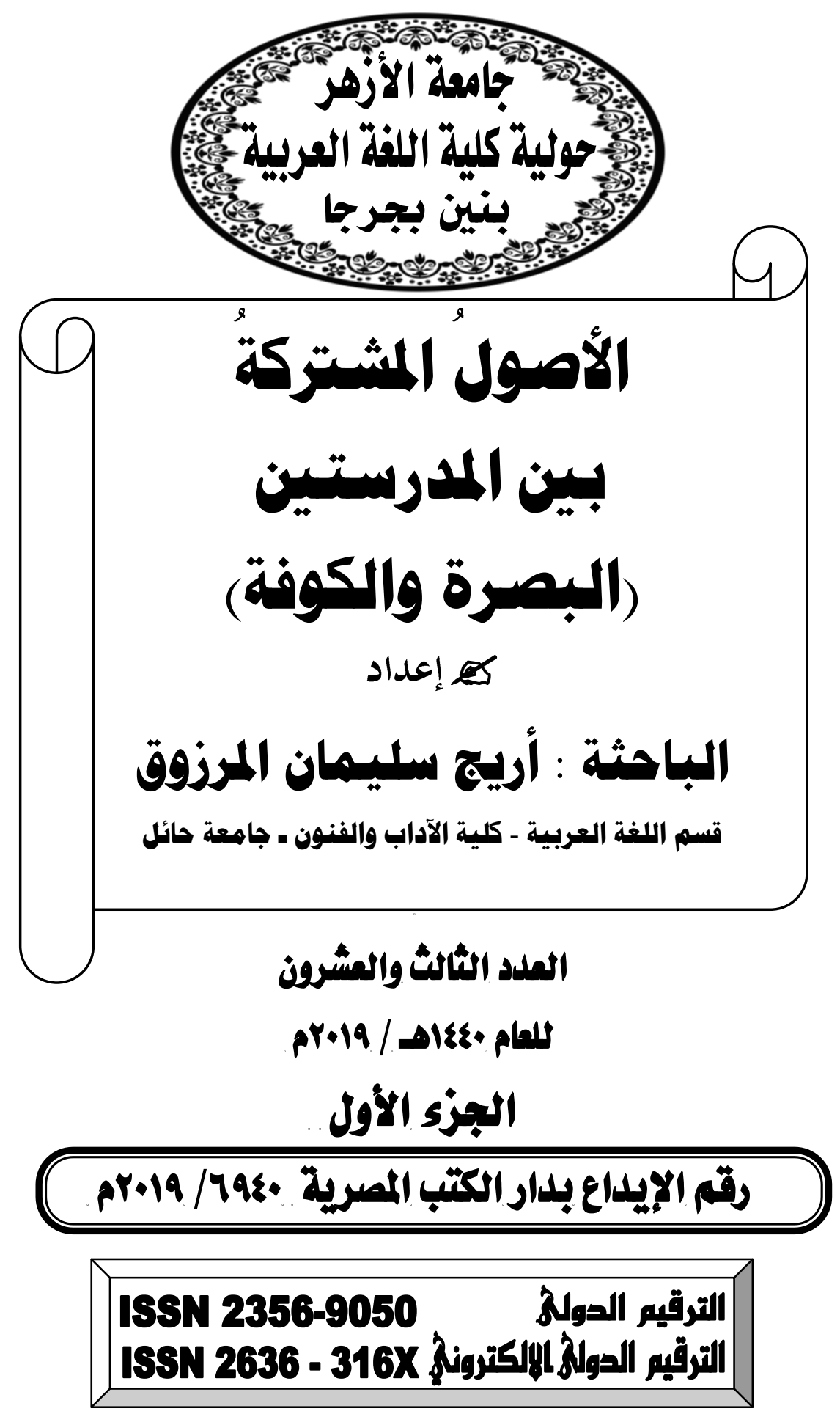


الأصول المشتزكةّ بـين المدرستين (البصرة والكمفةة)

كان بين مدرسة البصرة ومدرسة الكوفة خلاف في كثير من المسائل

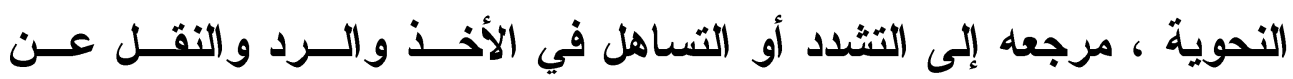
الأعر اب، لكن لا يمنع ذلك وجود اتفاق بين المدرستين .

لاللك سوف يقوم هذا البحث على عرض الأصول التي اتفقت عليهـا

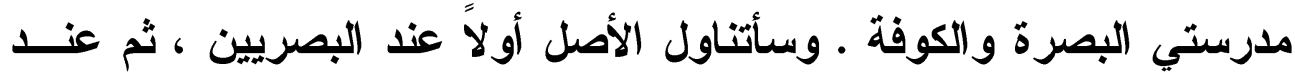
الكوفيين ، مع ذكر الأمثلة التي توضع هذا الاتفاق •

\section{كمل إعداد}

\section{الباحثة : أريج سابيمان المرزوق}

قسم اللغة العربية - كلية الآداب والفنون ـ جاهعة حائل

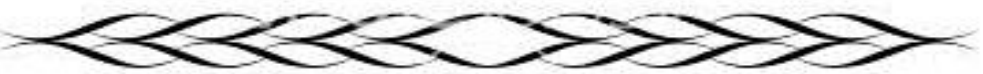




\section{الترقيم الدوله \\ ISSN 2356-9050}

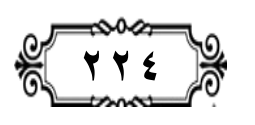

حولية كلية اللفة العربية بجرجة مجلة مجلة

\section{Research Summary}

The common assets between the two schools (Basrah and Kufa)

Between the Basra school and the Kufa school there was disagreement in many grammatical issues, due to the strictness or leniency in the introduction, response and transportation of the expressions, but this does not preclude an agreement between the two schools.

Therefore, this research will present the assets agreed upon by Basra and Kufa schools. I will discuss the original first with the Basrien, then with the Kufis, with examples that illustrate this agreement.

Preparation

Researcher : Areej Sulaiman Al Marzouk

Department of Arabic Language - Faculty of Arts and Arts Hail University 


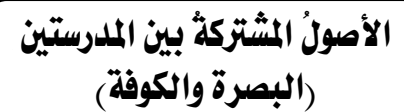

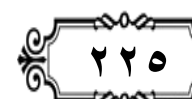

العدد الثالث والعشرون للعام 19. العزم الجزء الأول

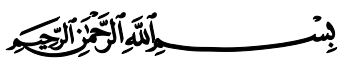

مقدمة : مقدة :

منذ أن نشأت مدرستا البصرة والكوفة نشأ اختلاف بينهما في الفكـر النحوي. وإن كان بالطبع لا يعني عدم وجود اتفاق بين هاتين المدرستين ، فقد كان هناك اتفاق في الأصول النحوية بينهما. وعُرف عن مدرسة البصرة طابعُ التشدد ، والتقصي ، والحرص في الأخذ ، والنقل عن الأعراب. بينما نجد في المقابل الكوفة تساهلت في الأخذ عن الأعراب إلى حّّ ما بالمقارنة ميع البصرة. ولكن في النهاية اتفقت المدرستان علــى أن الســماع ، والقيــاس، واستصحاب الحال أصولاً من الأصول، التي ينبغي اتباعُها لاراسةِ اللغة . وسأعرض في هذا البحث الأصول التي اتفقت عليهــا المدرســتان . وسأتناول الأصل أولاً عند البصريين ، ومن ثم عند الكوفيين ، مـــع ضــرب

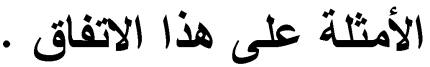

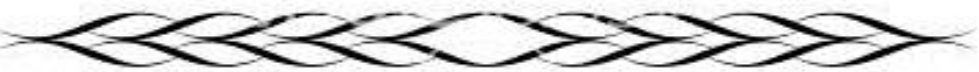




\section{الترقيم الدوله \\ ISSN 2356-9050}

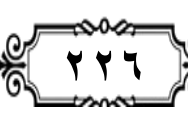

\section{الفصل الأول : السماع}

"يقصد بالسماع : الأخذ عن الأعراب الفصحاء ،ونقل لغاتهم، وتسجيل

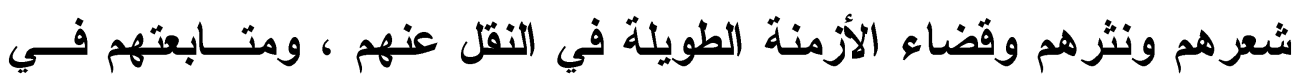
حياتهم اليومية ." (1)

و" يُروى أن الكسائي بعد أن استوفى ما عند علماء الكوفة ،رحل إلى ألى

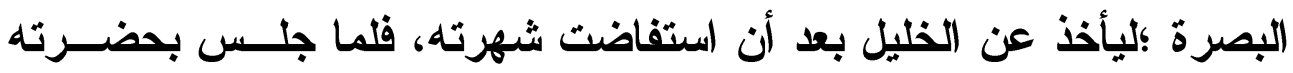

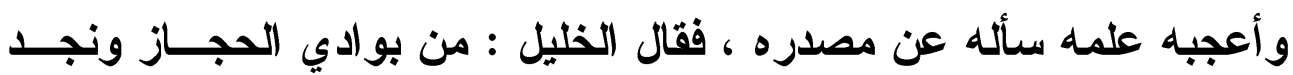

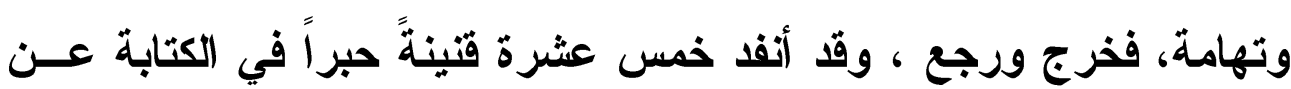

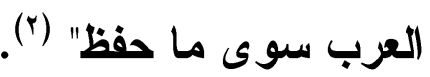

"وروي عن الأصمعي عن أبي عمرو أنه قال :" ما سَمِعَ حمادٌ الراويةُ

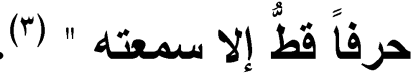 \\ السماع عند البصريسين:}

"البصريون في أخذهم عن العرب لم يكونوا يجمعون كل ما يصادفهر

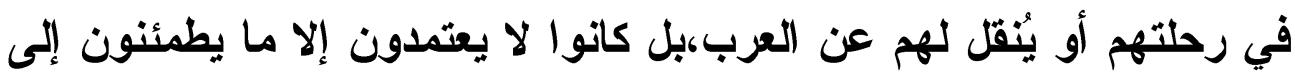

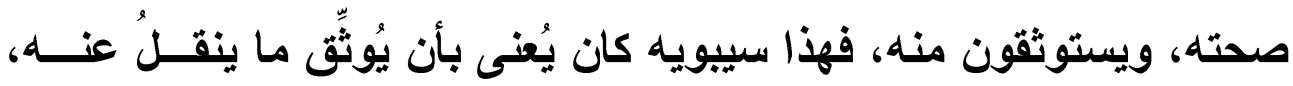

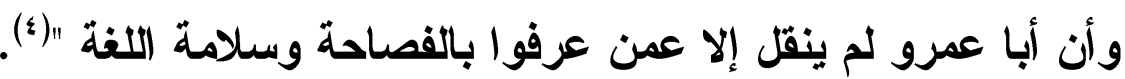

(1) مدرسة البصرة النحوية نثأتها وتطورها ، عبد الرحمن السيد ، الطبعة الأولى، ص بـاسب.

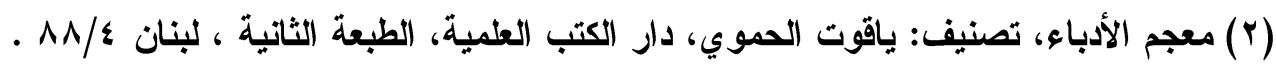

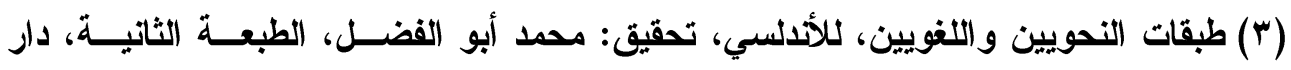

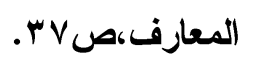

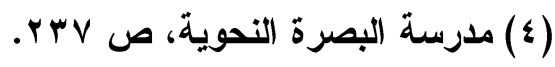




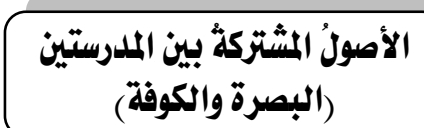

\section{PrV

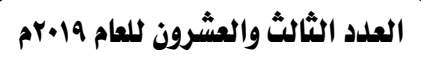

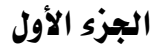

ومن خلال دراسنتي وبحثي عن مدرسة البصــرة، واعتمادهــا علـى السماع سألخص موقفهم في مجموعة من الخطوات:

() كانوا يتجهون إلى البادية يطلبون صفاءها، ونقاءهــا. لا يقصــدون إلا

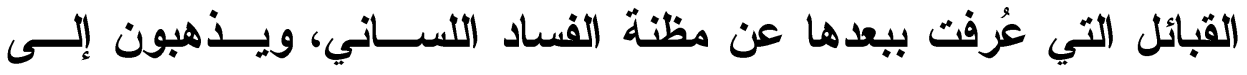
المواطن التي اثتهرت بجودة الأساليب. فهم تركوا الحاضرة ؛ لأن لغات

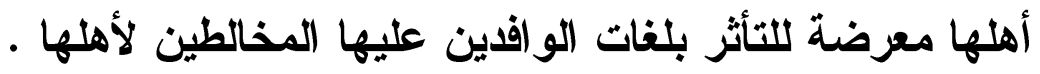
r) تركوا القبائل المجاورة للأعاجم التي يمكن أن تتصل بينها وبينهم أسباب

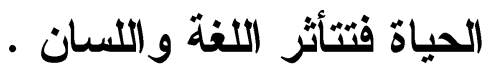

ץ) كانوا أثثد حرصاً على أن يتلقوا من فصحاء الأعــراب الــنين يــردون

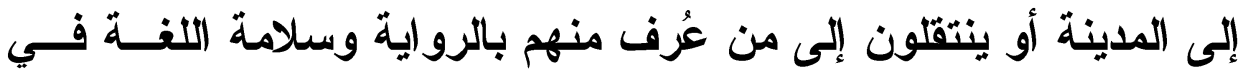
باديته

ويعرض ابن جني مصادر اللفة الصافية وأنها كاتت في البوادي دون الحواضر يقول : "إن العبب في ترك الأخذ عن أهل المدر ما عرض للغاتهم

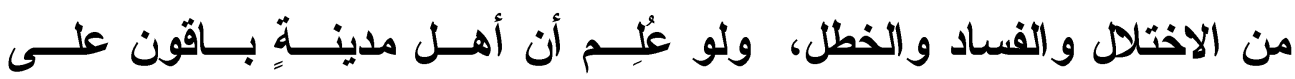

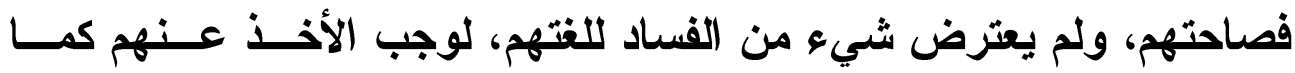

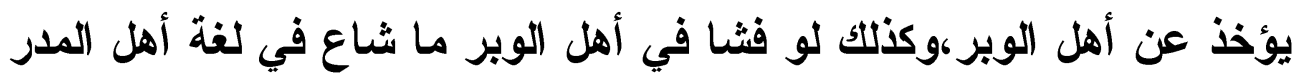

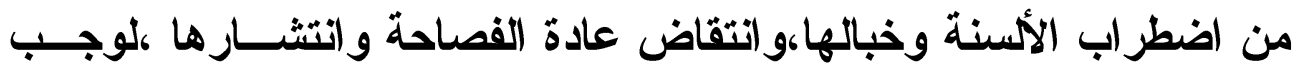

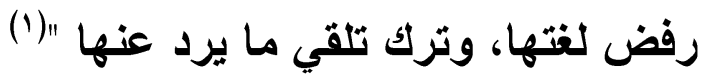

(1) الخصائص لابن جني، تحقيق: عبد الحميا هندواي، دار الكتب العلمية ،الطبعـة الثالثـة،

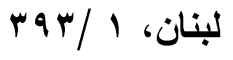

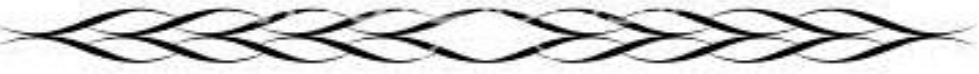




\section{الترقيم الدوله ISSN 2356-9050}

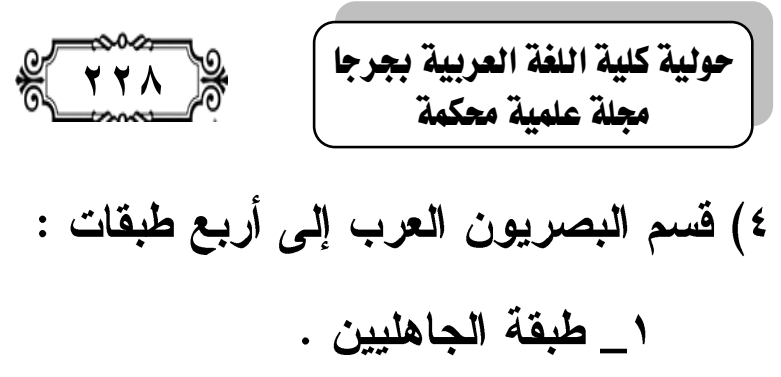

r طبقة المخضرمين من الأين أدركوا الجاهلية والإسلام ،وهاتــان الطبقتان يستشها بشعرها في رأي جميع العلماء ،ولم يخالف في ذللك أحد. r_طبقة الإسلاميين كجرير والفرزدق و الكميت وذي الرمة. وهـــه

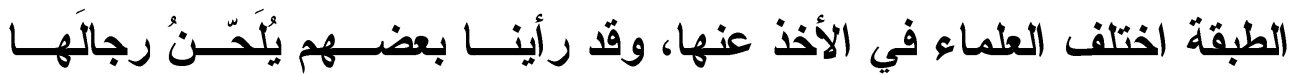

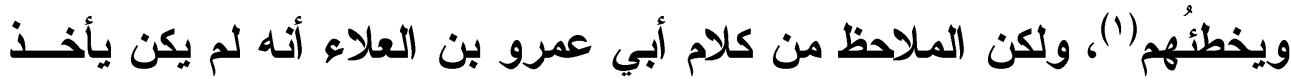

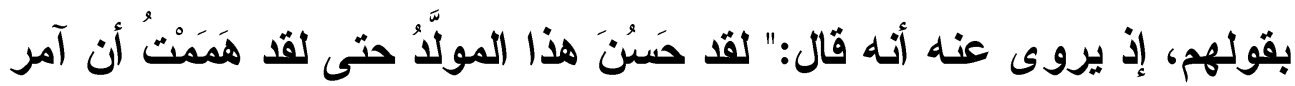

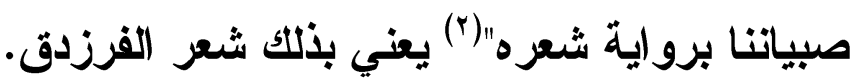
ولكن معظم العلماء رجحوا جواز الأخذ عـن رجالهــا فاستثـــهـوا

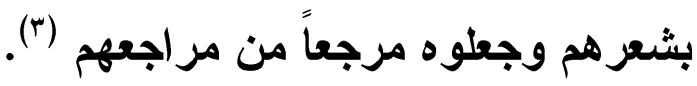
عـ فهي طبقة المولدين و المحدثين، وهم مَنْ بعدَهم إلى زمانتا، وأول

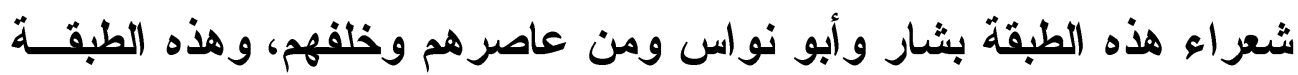

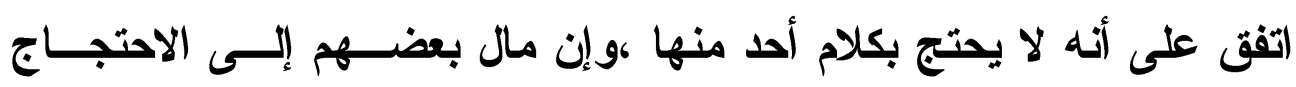

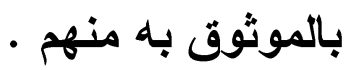

وكما اتفقوا على أنه لا يُحتج بشعر المحثثين قــالوا : إنـــه لا يجــوز

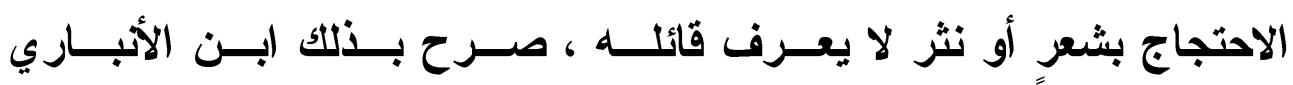
(1) خزانة الأدب، تأليف: البذادي، تحقيق: عبد السلام هـارون، مكتبـة الخــاتجي، الطبعـة

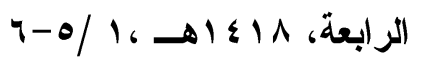

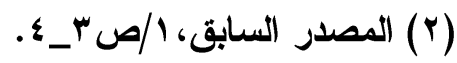

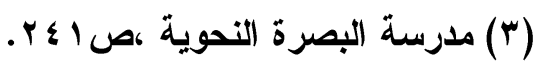




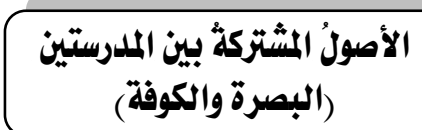

rra

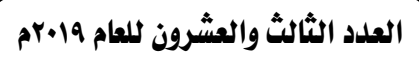

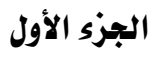

في الإتصاف(1)، وكان علة ذلك خوف أن يكون لمولــــ أو لمـن لا يوثــق

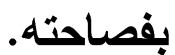

حيث قال إن هذا البيت غير معروف ولا يعرف قائله ؛ فلا يكون حجة. فهذا المسلك الذي سلكوه في رواية اللغة، وهذا هـــو الــنهج الـــي

ساروا عليه في السماع من العرب ، تظهر فيه دقة البحث، وعمث الفكر (؟). "وأيضاً تركوا الاستشهاد بالحديث النبوي ولم يتذذوه إماماً لثواهدهم

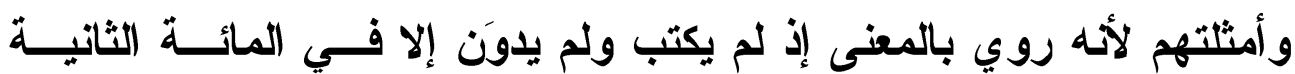

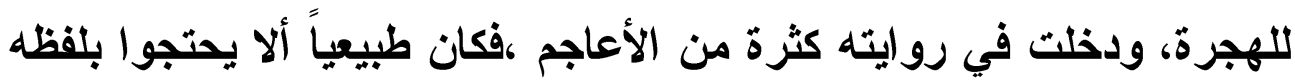
وما يجري فيه من إعراب " (") .

ويبدو لي أن تركهم للاحتجاج بالحديث النبوي فيــهـ إجحساف ؛ لأن

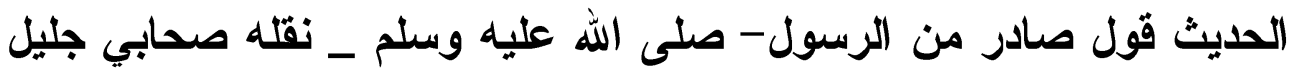

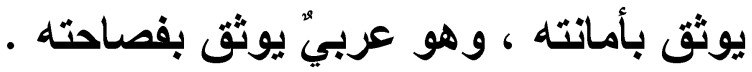

وبالنسبة للقراعات ترك نفر منهم أحرفاً قليلة فيها لا تكــاد تتجــاوز

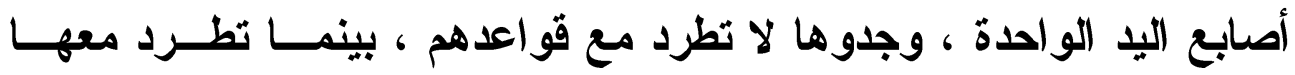

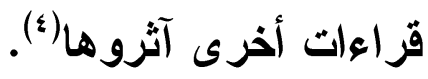

(1) انظر : الإنصاف ، لابن الأبباري ، تحقيق: جودة مبروك، الطبعة الأولــى، الناثــر مكتبـة

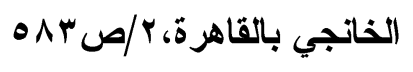

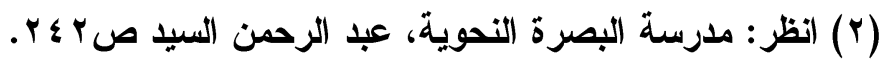

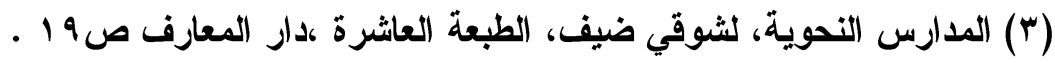

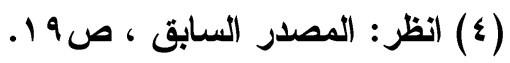


الترقير الدول\$ ISSN 2356-9050
Q
حولية كلية اللفة العربية بجرجا مجلة علمية محكمة

\section{السمثاع عند الكوفيسين :}

لعل أهم ما يميز المدرسة الكوفية عن المدرسة البصرية اتساعها في رواية الأثنعار، وعبار اتِ اللغة عن جميع العرب ،بدويِّم وحضريِّهم ، بينما

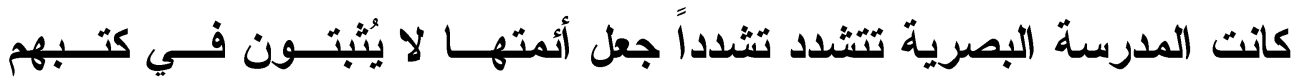
النحوية إلا ما سمعوه من العرب الفصحاء ،الأين ســلمت فصــاحتهم مــن شوائب التحضر وآفاته.

وليس معنى ذلك أن أئمة الكوفة لم يكونوا يرحلون إلى هذه القبائسلـل الفصيحة، فقد كانوا يكثرون من الرحلة إليها، على نحو ما يحــثنا الــرواة عن الكسائي(ت: ب 9 اهـ)، فقد قالوا: "إنه خرج إلى نجد ،والحجاز ،وتهامة ورجع وقد أنفد خمس عشرة قنينة حبر في الكتابة عن العرب ،سـوى مــا

حفظ "(1)

ولقد كان الكوفيون ـ وفي مقدمتهم إمامُهم الكسائي _ لا يكتفون بما يأخذون عن فصحاء الأعراب ، إذ كانوا يأخذون عمن سكن من العرب فـي حواضر العراق ، وكثير منهم كان البصريون لا يأخــذون عــنهم ولا عــن قبائلهم المقيمة في مواطنها الأصلية مثل تغلب وبكر؛ لمخالطتها الفــرس ، ومثل عبد القيس النازلة في البحرين ؛لمخالطتها القرس والهند . فالبصرة تتشدد في فصاحة العربي الأي تأخذ عنه اللغــة والثــعر ، والكوفة تتساهل قليلاً فتأخذ عن الأعراب الأين قطنوا حواضر العراق، مــــا جعل بعض البصريين يفخر على الكوفيين بقوله :

(1) إنباه الرواة على أنباه النحاة ، تأليف: جمال الاين القفطي ، تحقيق: محمد أبــو الفضـل ،

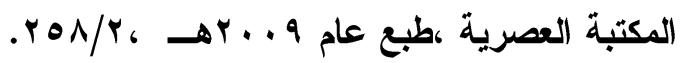


"تحن نأخذ اللغة عن حرشة (أكلة) الضباب ،وأكلة اليرابيع (أي البدو

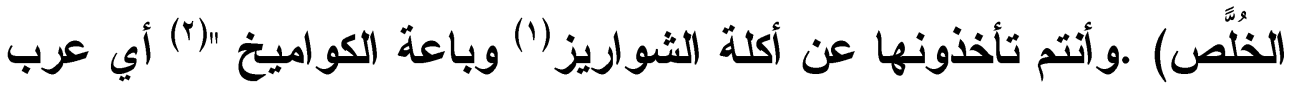

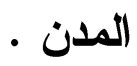

ولكن مع هذا الاختلاف نجد أن المدرستين اعتمدتا الســماع أصــلاً

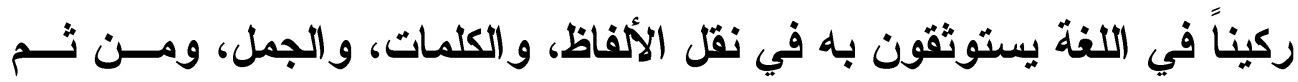

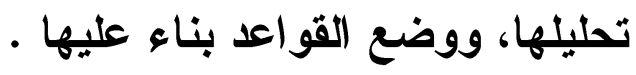

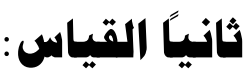

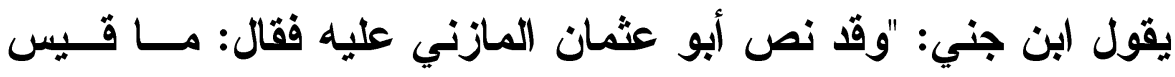

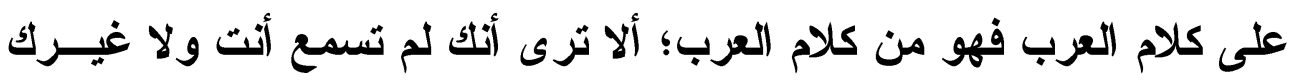

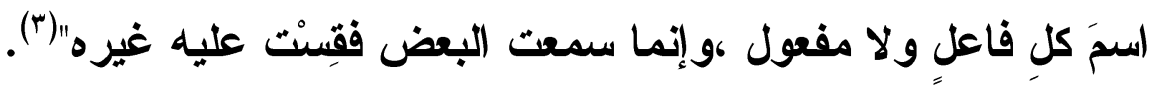

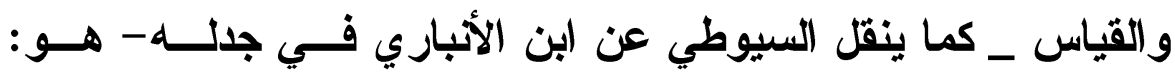

"حَمُ غير المنقول على المنقول إذا كان في معناه "(\&).

قال: "وهو معظم أدلة النحو والمعول في غالب مسائله عليه." (•) "و النحو قياس ؛لأن اللغات ليس من اليسير بل يكاد يكون من المحال الوقوف على كل مفرداتها ومشتثقاتها، وسماع كل كلمة منها في استعمالاتها

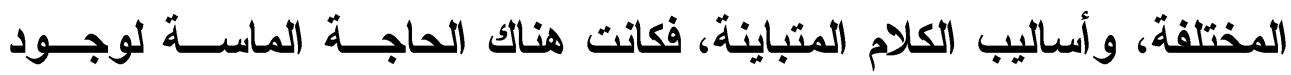

$$
\begin{aligned}
& \text { الثواريز : جمع شيراز وهو اللبن الرائب المصفى. } \\
& \text { الكواميخ : جمع كامخ وهو مخلل يثهي الطعام. }
\end{aligned}
$$

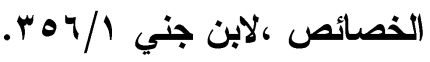

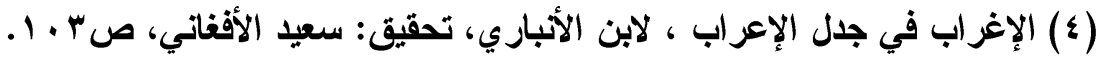

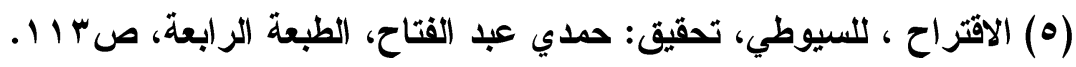




\section{الترقيم الدوله \\ ISSN 2356-9050}

الاستقر اء الممكن الكافي لوضع قاعدة، وبهذا يقاس ما لم يسمع عـى مـــ

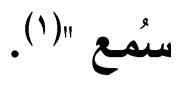

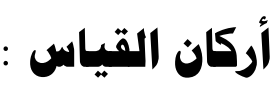

للقياس أربعة أركان: أصل وهو المقيس عليه، وفرع وهو المقيس ،

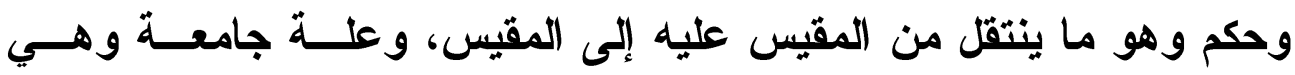

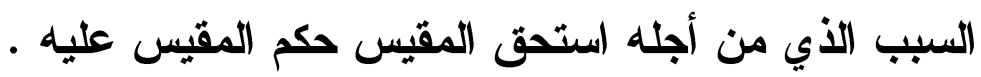

\section{القياس عند البصريين : اس}

لقد كان عبد الله بن أبي إسحاق أول من فكر في المقاييس النحويــة،

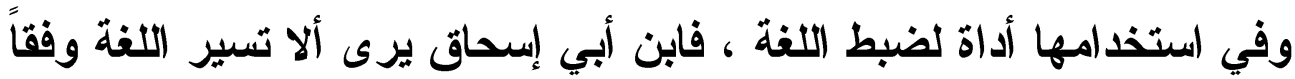

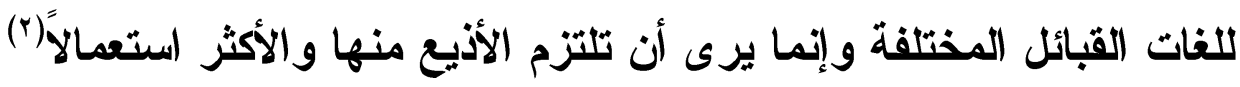
وقد قال عنه ابن سلام الجُححي في طبقاته إنه:" أول من بعج النحو،

ومَّ القياس و العلل"(").

و أبو عمرو ينحي منحى ابن أبي إسحاق ويـرى أن ضــبط اللغــة

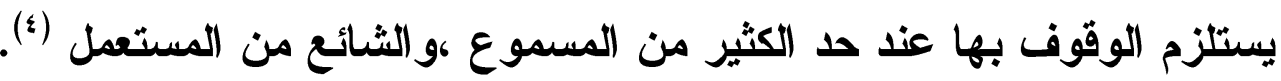

(1) مدرسة البصرة النحوية ،صب ع ب.

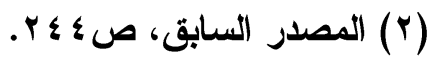

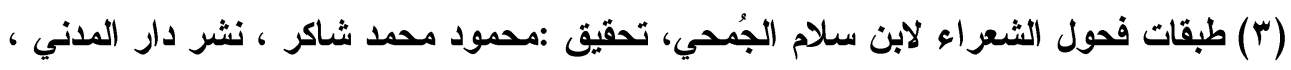

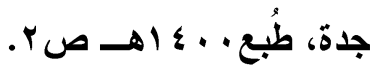

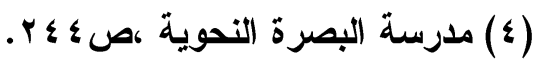




\section{الأصولُ المشتركةُ بين المدرستين

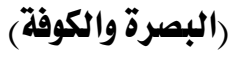

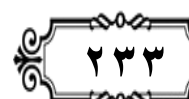

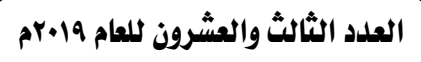

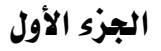

أما يونس بن حبيب فهو يوافق الكوفيين حيث إنه لم يقف في القياس

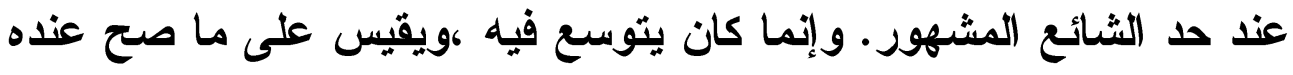
كما فعل ذلك الكوفيون.

و القياس قد وصل على يد الخليل وتلميذه سيبويه إلى تمــام نضـجه

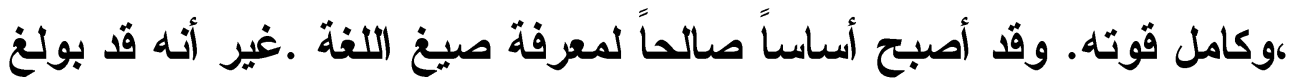

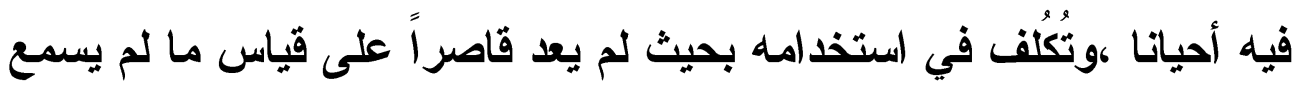

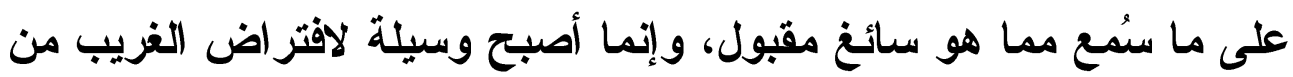
(الصيغ (1)

ونلاحظ أن البصريين اثثترطوا في الثواهد المستمد منها القياس أن

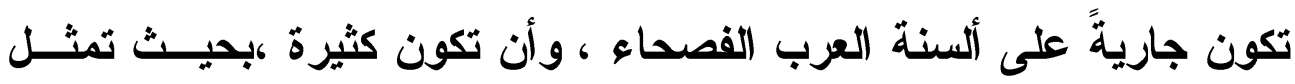
اللهجة الفصحى ،وبحيث يمكن أن تستنتج منها القاعدة المطردة . وبذلك أحكموا قواعد النحو وضبطوها ضبطاً دقيقاً ، وأيضــاً أخـــوا يرفضون ما شذ عن قو اعدهم و مقاييسهم لسبب طبيعي ، وهو مـــ ينبغـي

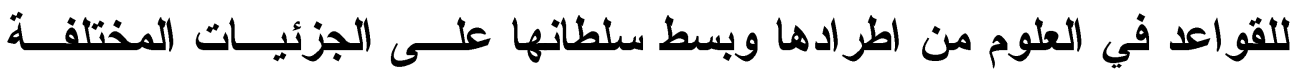

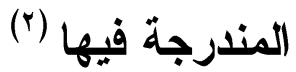
ومن ثم لم يجعل البصريون الثاهد الواحد بل الثاهد الناقص الذي لم

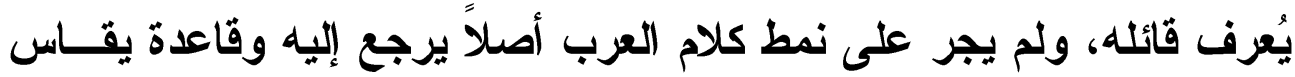

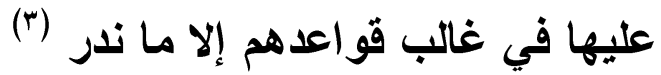

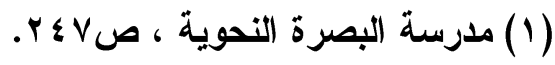

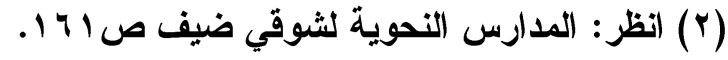

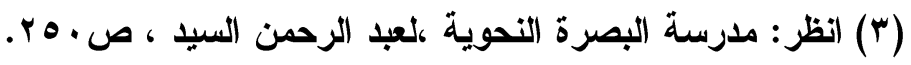


الترقير الدولخ ISSN 2356-9050

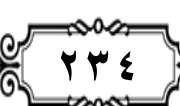

PrE
حولية كلية اللفة العربية بجرجا مجية مجلة علمية محكمة

\section{القياس عند الكوفيسن :}

اعتد الكوفيون بأقوال وأثثعار المتحضرين من العرب، كمــا اعتـدوا

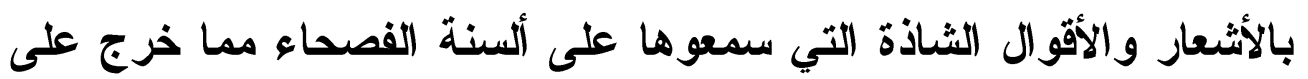

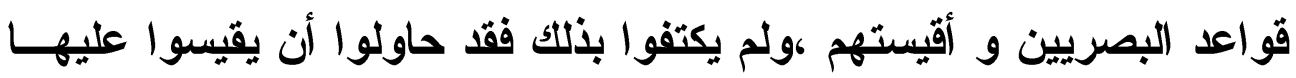

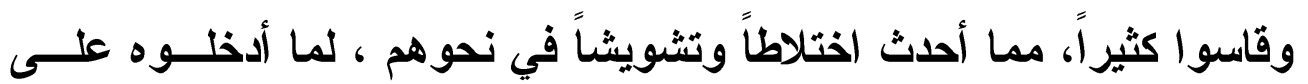
القواعد الكلية العامة من قواعد فرعية. (1) وقد قيل فيهم :"او سمع الكوفيون بيتاً واحداً فيه جواز شيء مخالف

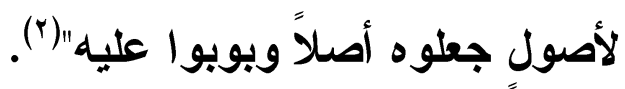
وقيل :"عادة الكوفيين إذا سمعوا لفظاً في شعر أو نادر كلام جعــوه

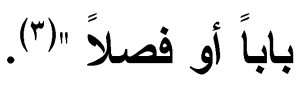

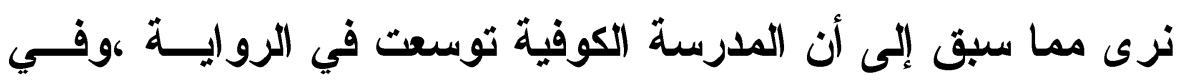

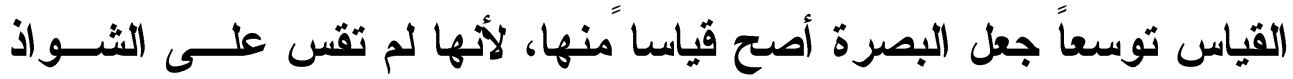

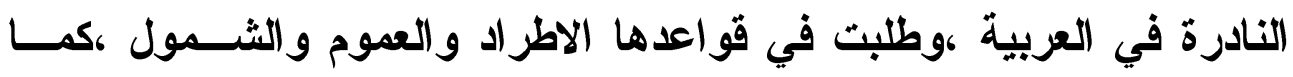

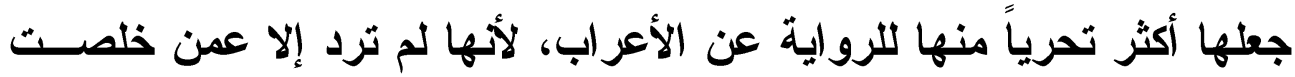

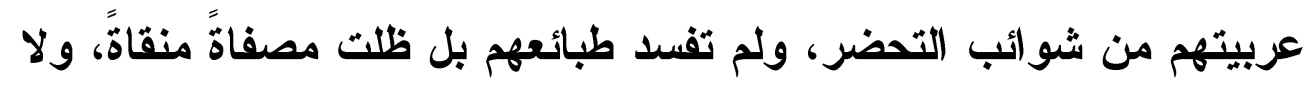
فسدت ألسنتهم بل ظلت تجري على عرق العروبة الأصل وإرثها القديم(\&).

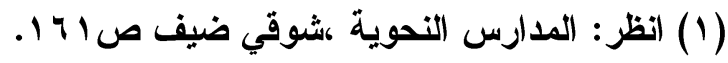

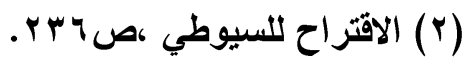

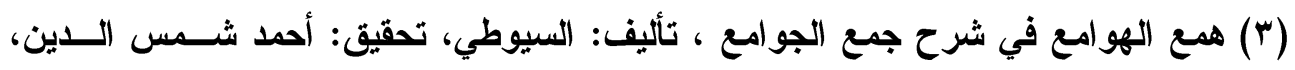

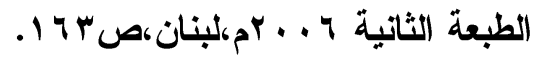

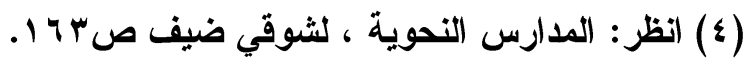


إلا أن توسع الكوفيين في مظان الاحتجاج وموارده جطهــم علمــاء

بالثعر حيث قال ابن جني : "فمن ثم أهل الكوفة أعلم بالثــعر مــن أهــل

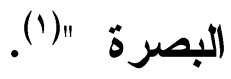

وأيضاً نراهم قد استخدموا القيــاس أحيانـاً دون اســتناد إلــى أي

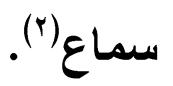

ولقد جعل الكوفيون القياس وحده أحياناً يتحكم بهم ، ويتخذ أساســاً

للغة ولو لم يسانده سماع(r)

ومع أن المدرستين قد اختلفتا في طريقة التناول للقياس ؛؛إلا أنهمــا

في النهاية متفقتان على أنه أصل عظيمٌ من الأصول النحوية التـي ينبغـي طئي الوقوف عندها ، والأطلاق منها إلى مدارسة اللغة ، ومعالجتها .

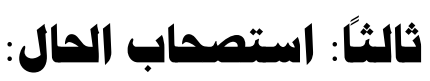

يعتبر استصحاب الحال من الأصول التي اتفقت عليهـــا المدرســتان

(البصرة و الكوفةة)

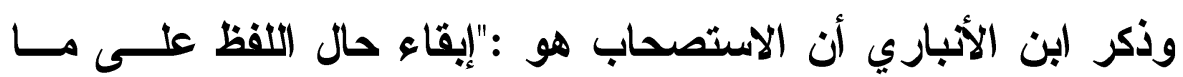

يستحقه في الأصل عند عدم دليل النقل عن الأصل"(๕)

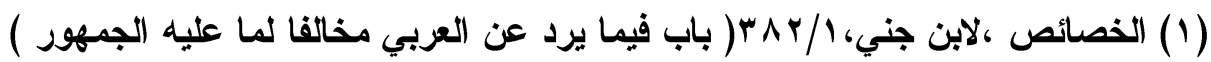

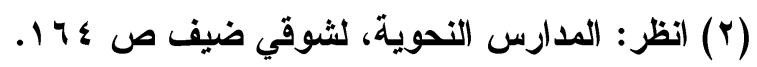

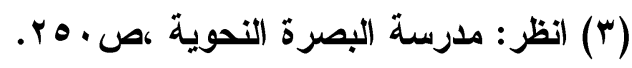

(ع) الإغراب في جدل الإعراب، تأليف : ابن الأباري،تحقيق: سعيد الأفغاني، مطبعة الجامعـة

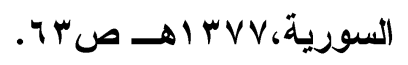


الترقير الدولخ ISSN 2356-9050
Pry

حولية كلية اللفة العربية بجرجا مجلة علمية محكمة

ويعتبر هذا الأصل من الأصول المستمدة من علم الفقه. (1) وقال في الإنصاف :"احتج البصريون على عدم تركيب "كم" بأن الأصل

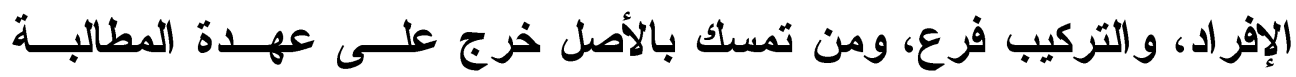
بالاليل، ومن عدل عن الأصل افتقز إلى إقامة دليل، لعدوله عـن الأصـلـ، واستصحاب الحال أحد الأدلة المعتبرة ". (r)

وقال الأدلالسي في شرح المفصل:" استدل الكوفيون على أن الضــمير في "لولاك" ونحوه مرفوع ، بأن قالوا: أجمعنا على أن الظاهر الأي قام هذا الضمير مقامه مرفوع، فوجب أن يكون كذلك في الضمير بالقياس عليــه ،

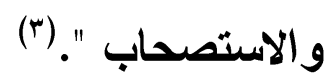

"ذهب الكوفيون إلى أن أداة الشرط (إنْ) تكون بمعنــى (إذْ)(الظرفيـة بينما قال البصريون أجمعنا على أن الأصل في(إن)أن تكون شرطاً والأصــل في(إذْ) أن تكون ظرفاً والأصل في كل حرف أن يكون دالاً على ما وُضع له في الأصل، فمن تمسك بالأصل فقد تمسك باستصحاب الحال ، ومن عدل عن

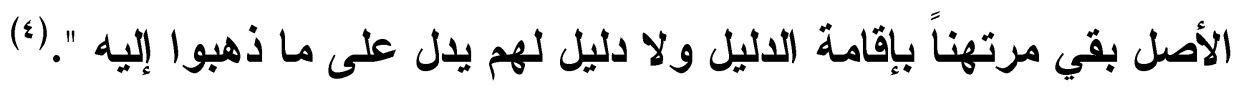
وقال (بن الأباري في:" استصحاب الحال من أضعف الأدلة، ولهذا لا يجوز التمسك به ما وُجِدَ هناكَ دليل، ألا ترى أنه لا يجوز التمسك بـــه فــي إعراب الاسم مع وجود دليل البناء من شبه الحرف، أو تضــمين معنـاه.

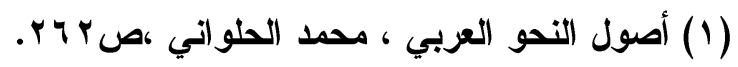

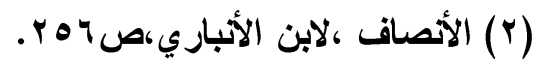

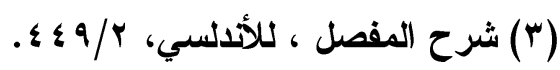

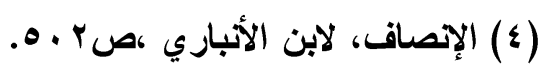




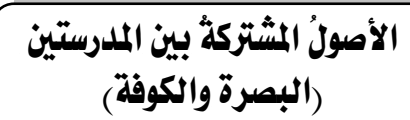

\section{PrV}

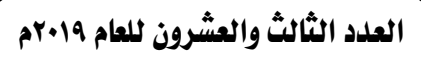

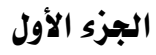

وكذلك لا يجوز التمسك به في بناء الفعل ،مع وجود دليـل الإعـراب مسن

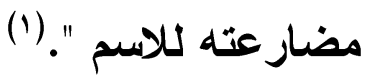

وعلى الرغم من استـلاههم باستصحاب الحال فــي هــــه المواضـــع

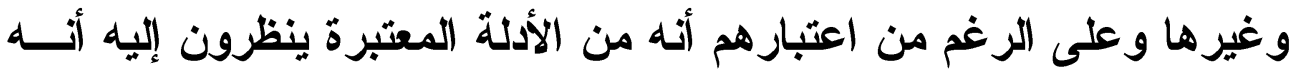

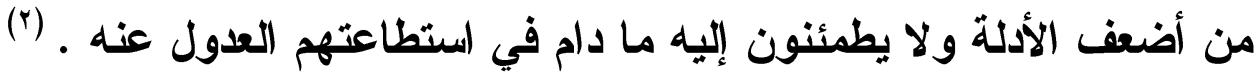
رابعًا: القواعد المشتركة بين البصريين والكوفيين :

هذا فضلاً عن أن المدرستين اتفقتا على الأصول العامة التي اســتـا

إليها النحو وهي السماع والقياس، واستصحاب الحال ،وإن كان هناك خلاف

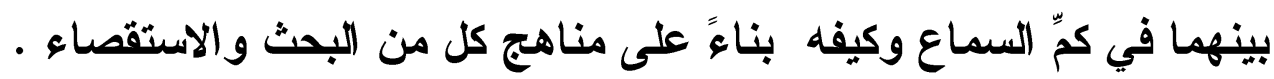
ومن هذه القواعد المشتركة:

ا__لا يجوز الجمع بين العوض والمعوض() :

اتفق على ذلك كل من البصريين والكوفيين واستدلو ا على ذلك بأدلة :

استدال البصريون بهذا الأصل على أن واو ربّ ليست هي العاملـــة ،

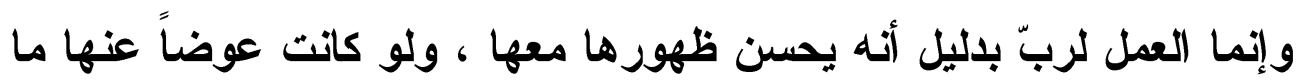

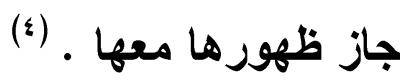

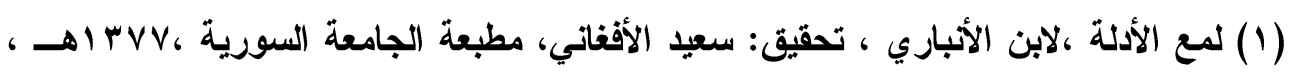

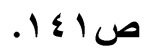

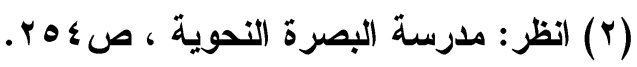

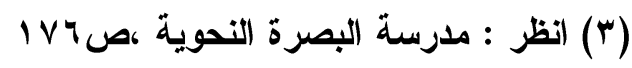

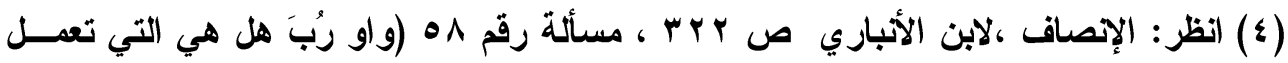

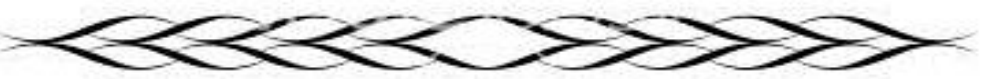




\section{الترقيم الدولخ}

ISSN 2356-9050

\section{Pri}

حولية كلية اللفة العربية بجرجا مجلة علمية محكمة

وكذلك استدلوا على أن واو القسم لما كاتت عوضاً عن البــاء لــ

يجز أن يجمع بينهما فلا يقال : وبالله لأثركنَ النفاق على أن يكونا حرفـي

قسم . (1)

واتفق معهم الكوفيون واستثلوا بعدم جواز الجمـع بـين العـوض

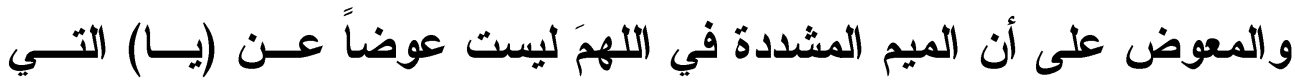

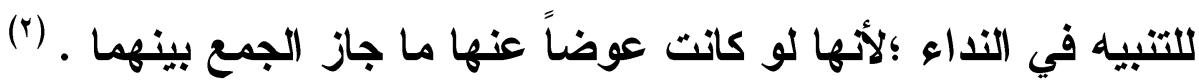

كما في قول الثاعر :

إِني إذا ما حدشُُ أنما

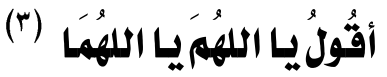

هنا جمع بين (يا) و اللهمَ فلو كاتت عوضاً عنها لم يجمع بينهما أي

بين الميم المشددة والياء

r) الحرف لا يعمل إلا إذا كان مختصاً (؛) :

إن كان الحرف غير مختص ،أي ياخل على الأسماء والأفعال وجـب

ألا يعمل ، كحرف الاستفهام ،وحرف العطف ؛لأنه تارة ياخل على الاســـ ،

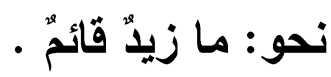

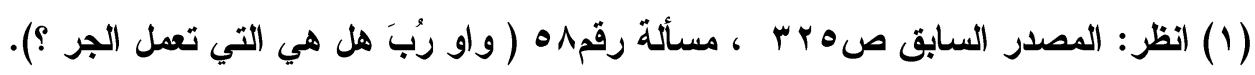

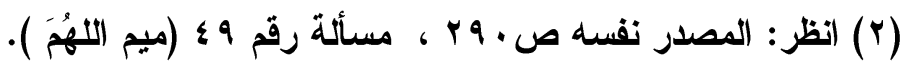

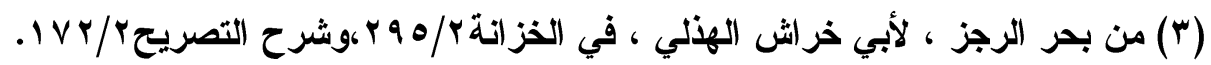

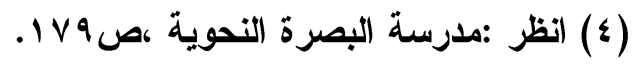


وتارة ياخل على القعل ،نحو: ما يقوم زيدّ .فهنا (ما) غير عاملــة ؛

لأنها مشتركة بين الأسماء والأفعال لذلك أهملت عند بني تميم وهــذا هــو القياس.

استدل البصريون بهذا الأصل على أن (لولا ) ليست رافعة للاسم دون

الفعل فإنها تدخل على الفعل كما تلخل على الاسم . (1) ومن ذلاك قول الشاعر :

هالا رميت ببعض الأسهم السود

لولا حددت ولا عذري لمحدود (r)
قالت أمامة لما جئت زائرها

$$
\text { لا دردرك إني قـد رميتهه }
$$

فإدخال لولا على الفعل دل على أنها لا تختص فوجب ألا تكون عاملة . وقدر الكوفيون ذلك بأنها مختصة بالاسم ،وأن( لو) التي في البيـــ

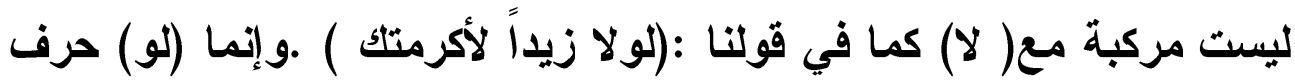

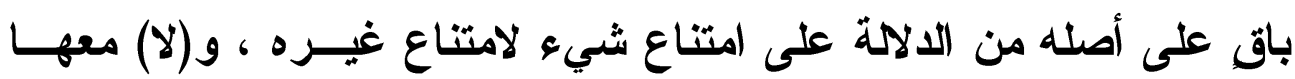
بمعنى(لم) ، لأن (لا) مع الماضي بمنزلة (لم) مع المستقبل ،فهي غير (لولا) التي وقع فيها خلاف ،فهي هنا مختصة بالأسماء دون الأفعـال ،فوجـب أن

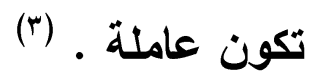

واستدل الكوفيون أيضاً بـ(ما) في لغة الحجاز لا تعمل في الخبر لأن

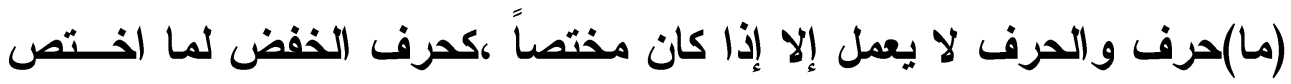

(1) (انظر : الإنصاف ،ص 97 مسألة (الاسم المرفوع بعد لولا ).

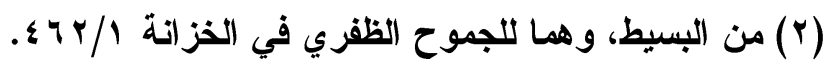

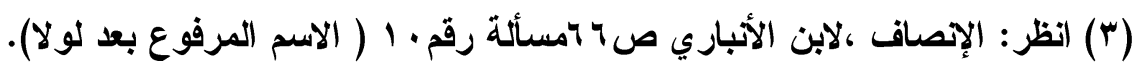




\section{الترقيم الدوله}

ISSN 2356-9050
Tre.

حولية كلية اللفة العربية بجرجا مجلة علمية محكمة الفية

بالأسماء عمل فيها، مثل قولنا : (من سار على الدرب وصل )فاختص حرف الجف

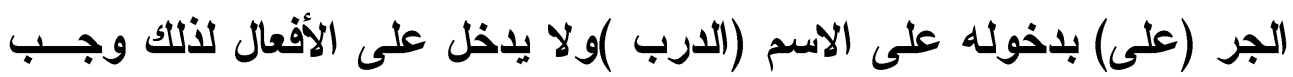
أن يكون عاملاً.

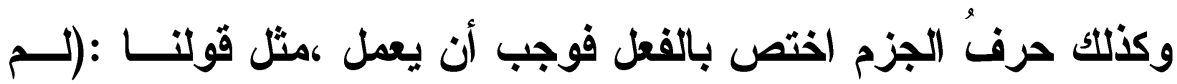

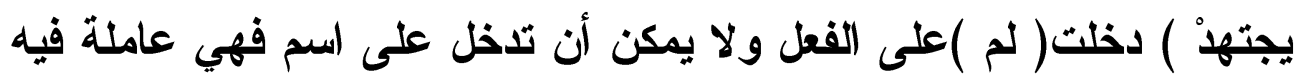

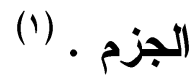

ץ)(الفروع تنحط دائماً عن درجة الأصول(†):

قال البصريون إن الضمير في اسم الفاعل إذا جرى على غير من هو

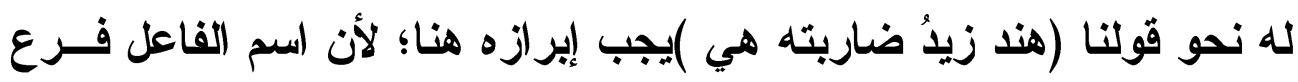

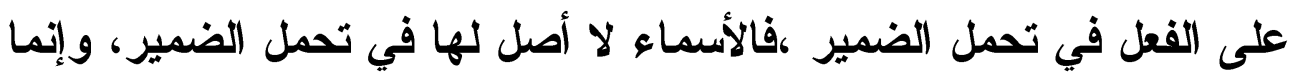

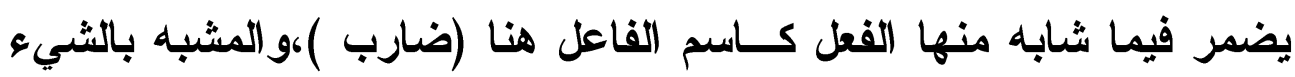

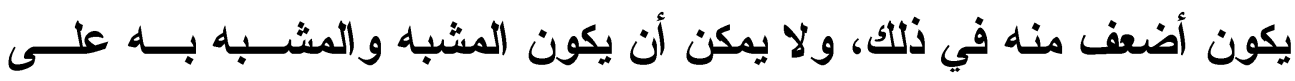

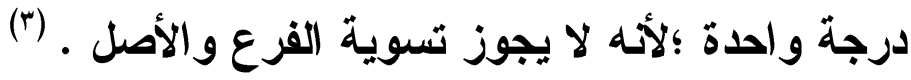
بينما مثَل الكوفيون لهذا الأصل بأن(إنَّ) وأخواتها لا ترفع الخبر؛ لأن

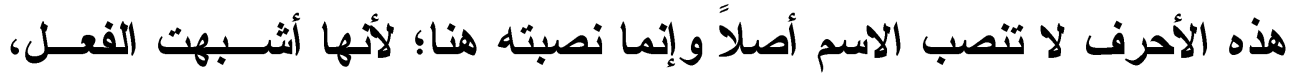

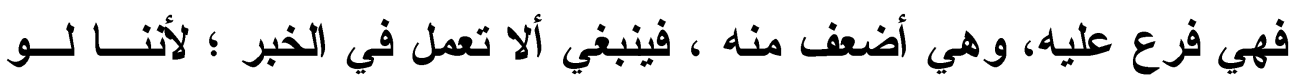

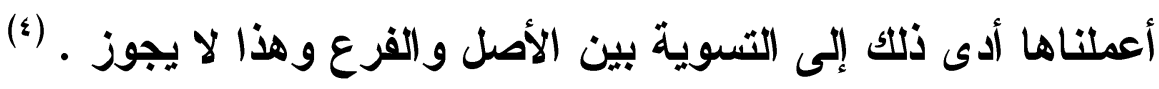

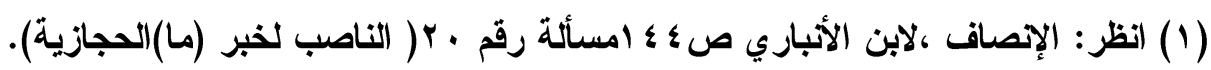

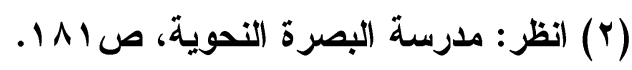

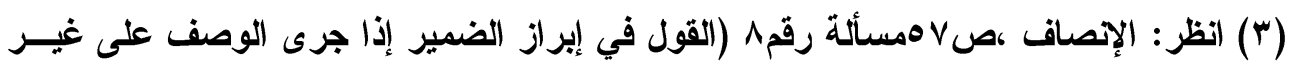




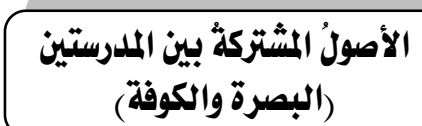

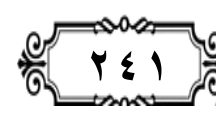

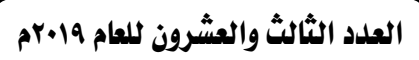

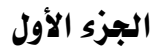

ومن الأمثئة أيضاً قال البصريون إن معمولات عليك و دونك وعنـــك

في الإغراء لا يجوز تقليمها عليها ،لأهها فرع في العمل على الفعل ،وإنما

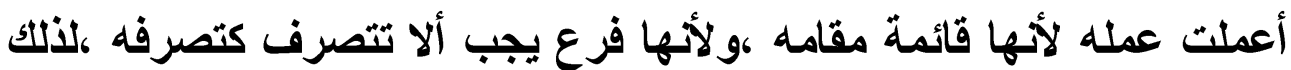

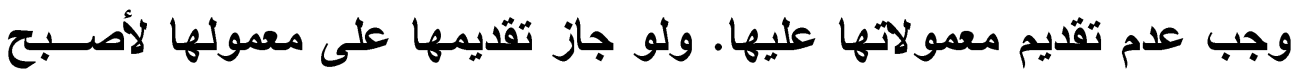

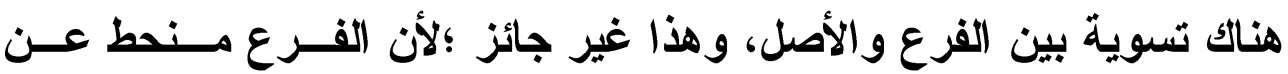

(الأصل . (1)

هذه الأمثثة التي ذكرتها وضحت لنــا اتفــاق كـلـ مـن البصــريين والكوفيين على أن الفرع منحط عن الأصل ،ولا يساويه في الارجة . §)|الأضعف لا يعمل عمل الأقوى (ז):

قال الكوفيون إن (ما) في لغة أهل الحجاز لا تعمل في الخبر ،والخبر

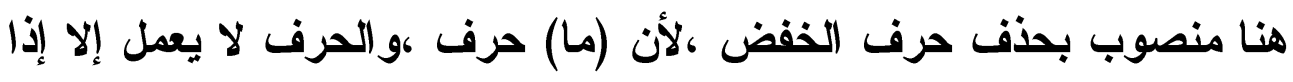

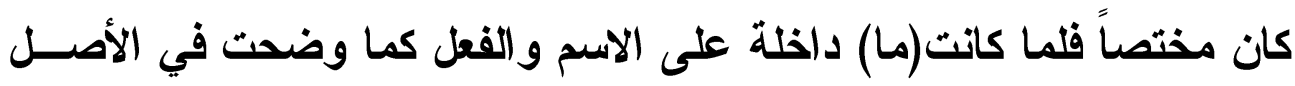
الثاني ، وجب ألا تعمل ولذلك أهملت عند بني تميم.

و إنما الحجازيون أعملوها لأههم شبهوها بـ (ليس) من جهة المعنى ،وهو شبه ضعيف لأن (ليس) فعل و(ما) حرف ،و الحرف أضعف من الفعـل لمنل

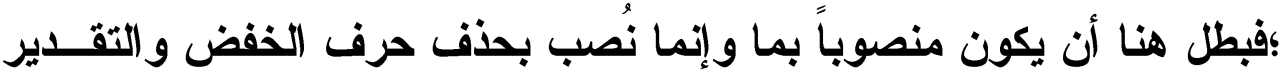

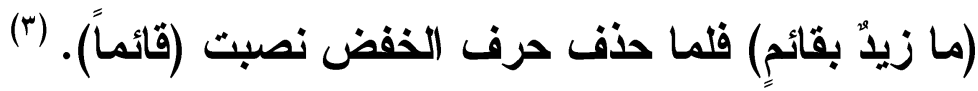

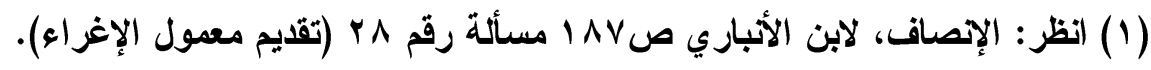

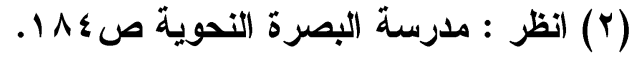
(") انظر: الإنصاف ،لابن الأثباري ص \& \& امسألة رقم • ب( الناصب لخبر ما الحجازية ). 


\section{الترقير الدولخ}

ISSN 2356-9050

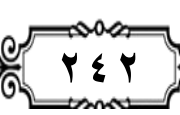

حولية كلية اللغة العربية بجرجا مجلة علمية محكمة الية الية اليه

و البصريون قالوا إن تثبيهنا (ما) بــ(ليس) أوجــب لهــا أن تعــل

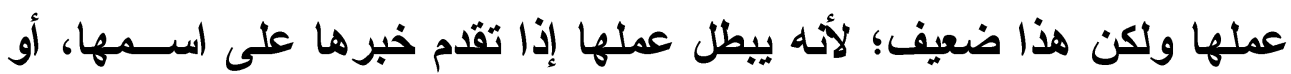

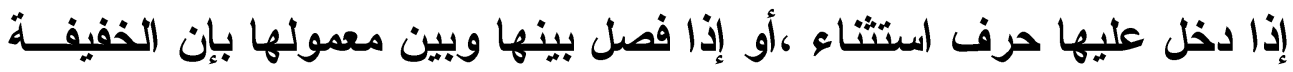

وبسبب هذا الضعف لا تعمل . (1)

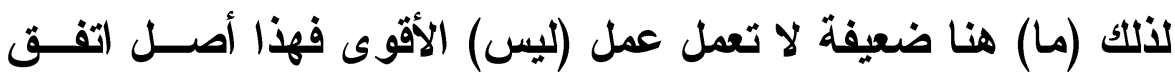

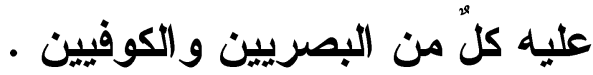
ه- اجتماع عاملين على معمول محال(") : اتفق كل من الكوفيين والبصريين على أنه لا يجوز اجتماع عـاملين

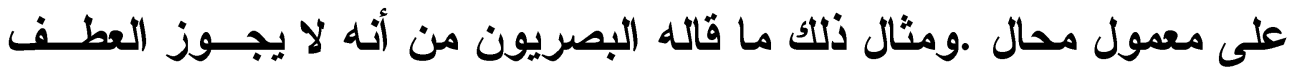

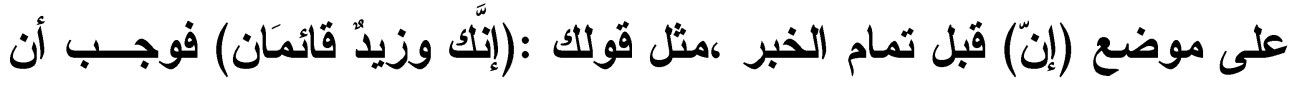

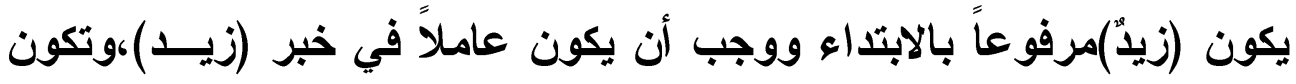

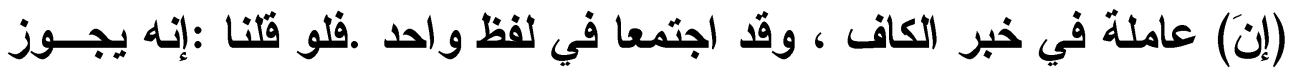

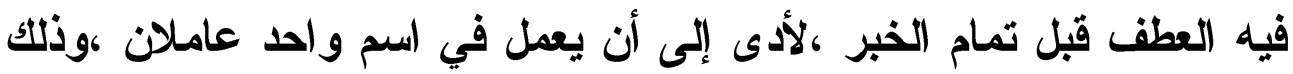

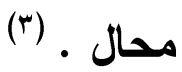

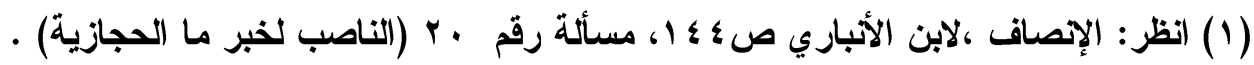

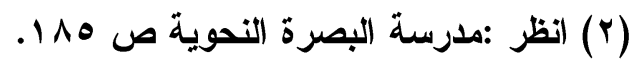

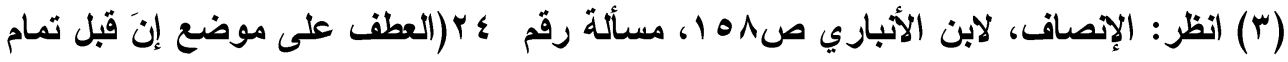

\section{0}




\section{العدد الثالث والعشروز للعام 19rra}

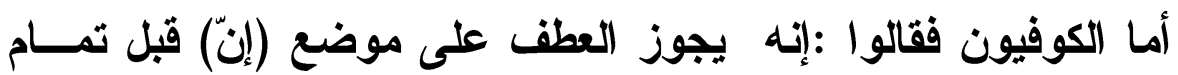
الخبر لأهـه يجوز العطف على موضع (لا) قبل ثمام الخبر مثل :( لا رجل ولا

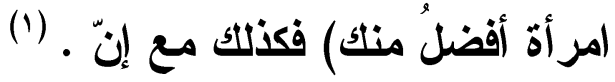

لاحظنا من خلال الأمثاثة التي أوردتها اتفاق أصداب المدرستين مسن

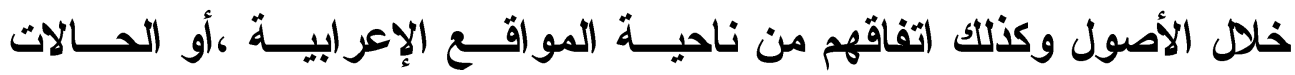
الإعر ابية وهي بالطبع ثدخل تحث ما بُسمى بـ (التوجيه النحــوي) وهـي مواضع تبين الاتفاق بينهم في غير الأصول ذكرتها هنا ، وهي:

1) اتفاقهم على رفع المبتدأ والخبر ، واختلافهم في عامهل الرفـع

فيهما ، حيث ذهب الكوفيون إلى أن المبثدأ يرفع الخبر، والخبر يرفع المبثدأ

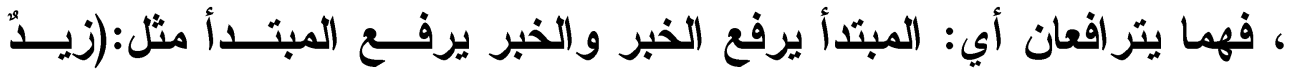
أخوك) زيدّ: مبتدأ والعامل في رفعه الخبر (أخوك) و (أخــوك)خبر مرفـوع و العامل في رفعه المبتدأ (زيد).

بينما ذهب البصريون إلى أنّ المبتدأ يرثفع بالابت داء ،وأمـــا الخبـر فاختلفوا فيه فذهب قوم إلى أنه يرتفع بالابتداء وحده، وذهب آخرون إلى أنه يرتفع بالابتداء و المبتدأ معاً، وذهب آخرون إلى أنه يرتفع بالمبتدأ ، والمبتدأ يرتفع بالابتداء فقد أجمعوا على رفع كل من المبتدأ والخبر. (r)

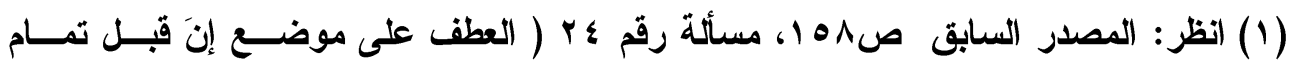
(الخبر)

(Y) انظر : الإنصاف ،لابن الأنباري ص • عمسألة رقم ه (رافع المبتدأ والخبر). (r) (المصدر ) السابق ص. ع .

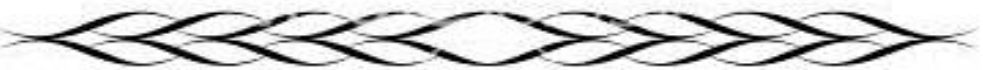




\section{الترقير الدولخ}

ISSN 2356-9050
Pin
حولية كلية اللفة العربية بجرجا مجلة علمية محكمة

r) اتفاقهم على رفع الفعل المضارع واختلافهم في عامل الرفع :

أجمع الكوفيين والبصريون على أنّ الأقعــال المضــارعة معربـــة ،

$$
\text { واختلفوا في علة إعر ابها . }
$$

وعلة إعرابها عند الكوفيين أنها إنما أعربت لأنها دخلهـا المعـاني

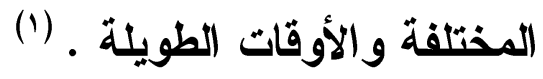

وعلة إعرابها عند البصريين تعود لأوجه ثلاثنة :

الوجه الأول: لأن الفعل المضارع يكون شــائعاً فيتخصــص كمــا أن الاسم يكون شائعاً فيتخصص ونضرب لأللك مثالاً:

كقولنا (يقوم ) يصلح للحال والاستقبال إذن هنا اللفظ شائع وإذا قلنا (سيقوم) اختص هنا بالاستقبال م

مثله مثل الاسم كقولنا :هذا رجل ( هذا اللفظ يدخل فيه كل الرجـال )

أما إذا قلت: (الرجل ) فيختص بشخص معين •

إذن شابه الفعل الاسم من هذا الوجه .

الوجه الثاني : كل" من الفعل المضارع والاسم تلخله لام الابتداء فقي

الفعل نقول: [إنّ زيداً ليقومُ ] وفي الاسم نقول : [ إنّ زيداً لقائمٌ ] .

فلما دخلت لام الابتداء على الفعل المضارع كما تلخل على الاسم دل على المشابهة بينهما ، ولا يجوز أنّ تلخل هذه اللام على فعل الأمر والفعل الماضي لذلك لـ يعربا .

(1) انظر: الإنصاف ،لابن الأبباري ؟ ؟ مسألة رقم VY (الأفعال المضارعة لم أعربت؟) 
الوجهه الثالسث: أثثبه الفعل المضارع الاسم لأنها يجري علــى اســم

الفاعل في حركته وسكونه كقولنا ( يَضْربُ)على وزن (ضَارب) في حركتـهـ

وسكونه لألك أُعرب الفعل المضارع كما أُعربت الأسماء .

r) اتفاقهم على نصب المفعول به واختلافهم في العامل :

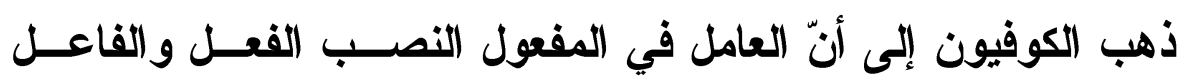

جميعاً.

وذهب بعضهم إلمى أن العامل هو الفاعل .

وذهب خلف الأحمر إلى أن العامل في المفعول معنــى المفعوليــة ،

والعامل في الفاعل معنى الفاعلية ـ (1)

بينما ذهب البصريون إلى أن العامل في المفعول الفعل وحده ،عمـل

في الفاعل والمفعول معاً. (r)

إذن هو منصوب عند الفريقين.

وفي هذا المثال ملت مع رأي البصريين وهو أن الفعل يؤثر ويعــلـ

الرفع في الفاعل والنصب في المفعول والله أعلم .

ع)(تفاقهم على أن (الآن) مبنيٌّ واختلافهم في علة البناء:

(1) انظر: الإنصاف ،لابن الأنباري ص VT مسالة رقم 11 (القول فـي عامـل النصـب فـي 


\section{الترقيم الدوله \\ ISSN 2356-9050}

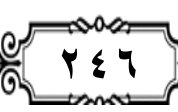

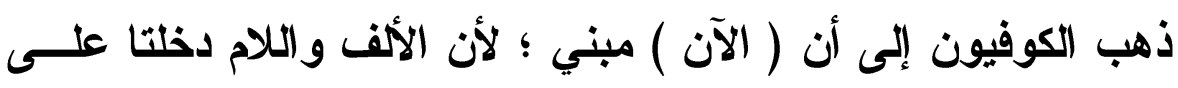

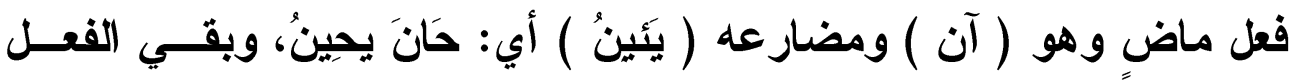

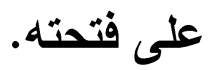

وذهب البصريون إلى أنه مبني لأنه شابه اسم الإثارة ـ (1)

ه) اتفاقهم على نصب الاسم المشغول عنه واختلافهم في عامل النصب : حيث ذهب الكوفيون في قولنا (زيداً ضربته) إلى أن العامل في نصبه

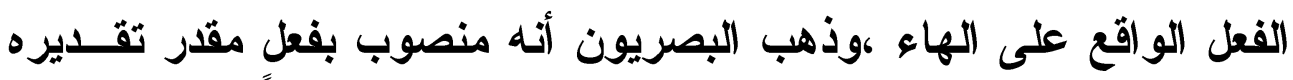

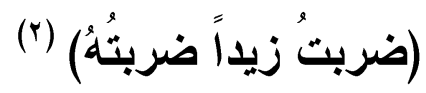
4)(تفاقهم على نصب الظرف إذا وقع خبراً للمبتدأ واخـتلافهم فـي

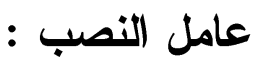

ذهب الكوفيون إلى أن الظرف ينتصب إذا وقع خبراً للمبتدأ كقولنــا:

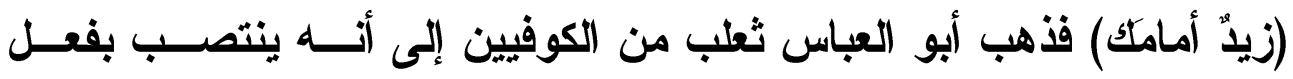

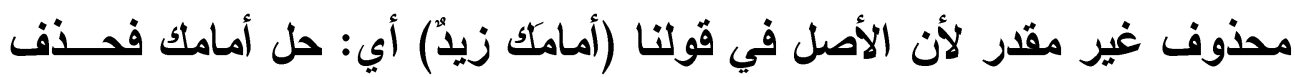

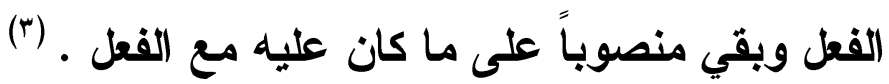
وذهب البصريون إلى أنه ينتصب بفعل مقدر والتقدير (زيــــ اســتقرَ

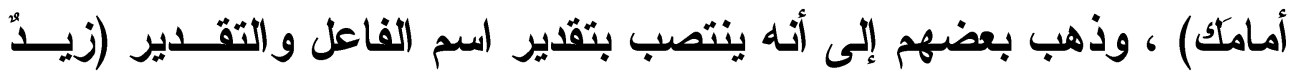
مستقر" أمامكك).

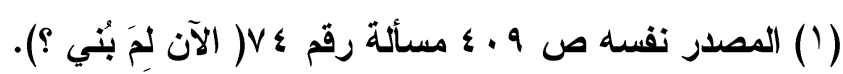

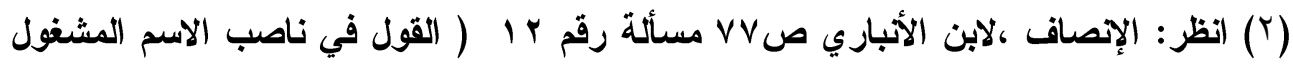

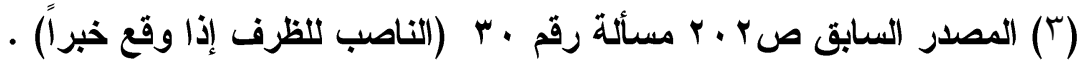


V) اتفاقه على إعراب الأسماء الستة واختلافهم في علة الإعراب : ذهب الكوفيون إلى أن الأسماء الستة وهي : أبوك، أخوك، وحموك، وهنوك، وفولى ، وذو مال ،معربة من مكانين، وذهب البصريون إلــى أنهــا

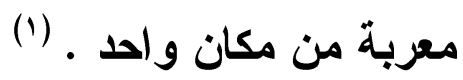

وحجة الكوفين أنها إنما أعربت من مكانين لقبة حروفها وليزيـدوا بالإعراب في الإيضاح والبيان لأللك أعربت من مكانين ،والمقصود بمكــانين

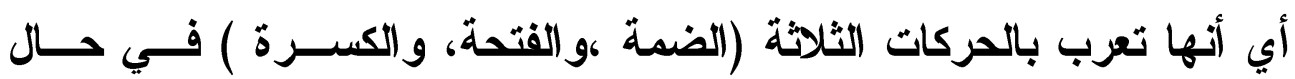
الإفر اد مثل قولنا (هذا أبِّ لك ، ورأيث أباً لك ، ومررث بأب لك) . والأصل (أبو) فاستثقلوا الضم على الواو فأوقعوه على الباء وأسقطت

وفي الإضافة في الرفع نقول :(هذا أبوك)

$$
\text { والنصب : (رأيت أباك) }
$$

والإضافة طارئة على الإفر اد ،فتكون الضمة والفتحة والكسرة التـي

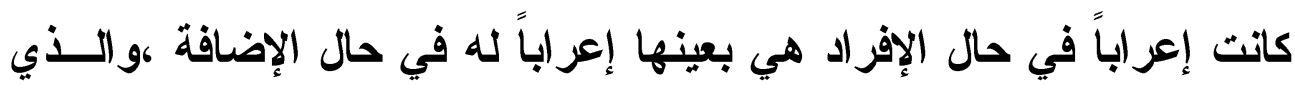
يذل على صحة هذا تغير الحركات على الباء ،وكذلك الواو و الألف واليــاء بعد هذه الحركات ،فل على أن الضمة والواو علامة الرفع، والفتحة والألف علامة النصب، والكسرة والياء علامة الجر، لذلك قلنا إنه معرب من مكانين. 


\section{الترقيم الدوله ISSN 2356-9050}

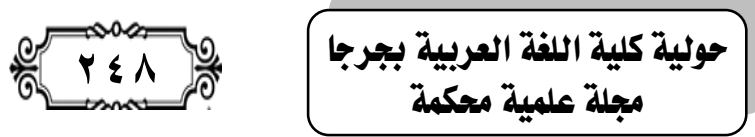

أمسا البصريون فاحتجوا بأن قالوا : إنه معرب من مكسـان واحسـ لأن

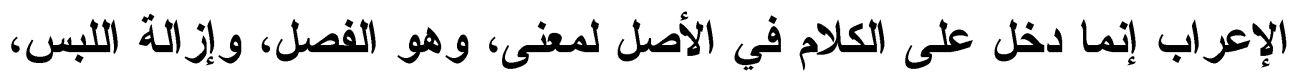

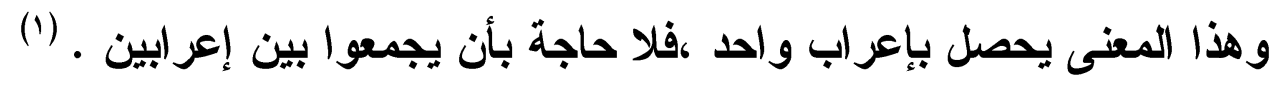




\section{* خـاتمهة :}

الحمد الله رب العالمين، والصلاة والســلام علــى أثــرف الأبيـــاء

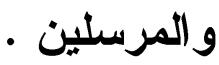

بتوفيق من الله وبفضله فقد توصلت في نهاية بحثي هذا إلى نتــائج كثيرة يمكن إجمالها فيما يلي :

_ اتفاق كُلٍِ من أصحاب المدرستين في الأصول وهي كامنة في الآتي

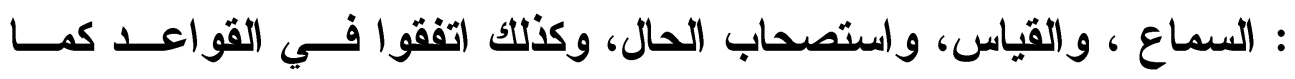
وضحت ذلك في البحث فعلى الرغم من وجــود الاخــتلاف وجــــ الآفــاق ووضحث ذلك بالأمثلة التي طرحتها وبينت فيها اتفاق المدرستين . _ كثرة وجود الاتفاق لاى نحاة المدرستين كما وُجد الاختلاف فيمـــا بينهم. ـ دراسة مسائل الاتفاق بين نحاة المدرستين يعمل على أن يجعل من النحو مادة سهلة بسيرة وأخيرًا:

اسأل الله عز وجل التوفيق والسداد إنه على ذلك قــدير ، وبالإجابــة 


\section{الترقيم الدولم ISSN 2356-9050}

1أصول النحو العربي ،تأليف :د. محمد الحلواني ،طبع في أفريقيا | + ب . r_الإغراب في جل الإعراب ،تأليف: الأبباري ، تحقيق : سعيد الأفغـــي ،

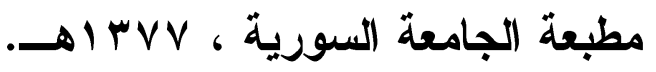

r_الاقتراح في علم أصول النحو، للسيوطي ، تحقيق: حدي عبد الفتــاح، مكتبة الآداب، الطبعة الر ابعة.

عـ_إنباه الرواة على أنباه النحاة ، تأليف : جمال الدين القفطي ، تحقيـق :

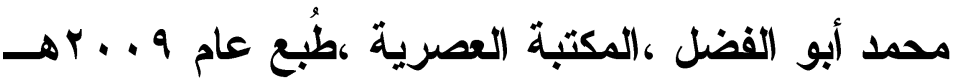

•_الإنصاف في مسائل الخلاف بين البصريين والكوفيين ، لابن الأبــاري ،

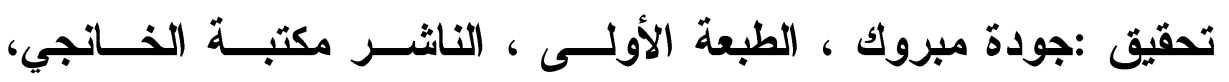
بالقاهرة.

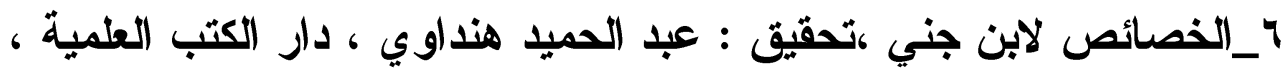

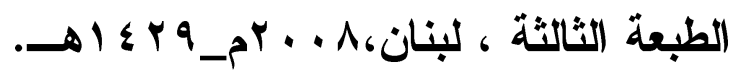

V_خزانة الأدب ، تأليف : البغدادي، تحقيق:عبد الســلام هـــارون، مكتبــة

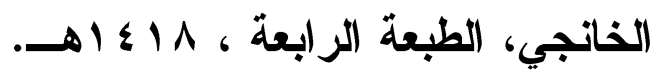

^_شرح المفصل ، للأنلالسي المسمى : المحصل في شرح المفصل، إعداد :

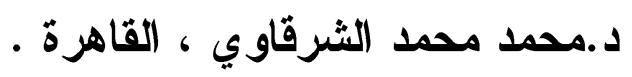

9_طبقات فحول الثعر اء لابن سلام الجُمحي ، تحقيق:محمود محمد شاكر ،

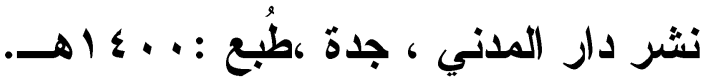




\section{الأصولُ المشتركةُ بين الملدرستين (البصرة والكوفة)}

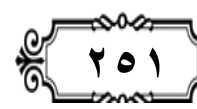

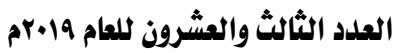

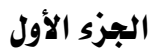

• 1 ـ طبقات النحويين و اللغويين ، للأندلسي ، تحقيق: محمد أبو الفضـل ، الطبعة الثانية ، دار المعارف .

ا_ـُمع الأدلة في أصول النحو، لابن الأبلاري ، تحقيق : سعيد الأفغـــي ،

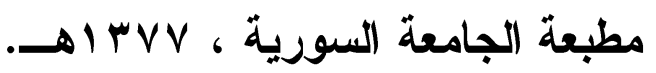

r Y _ المدارس النحوية ، لشوقي ضيف ، الطبعة العاشرة ، دار المعارف.

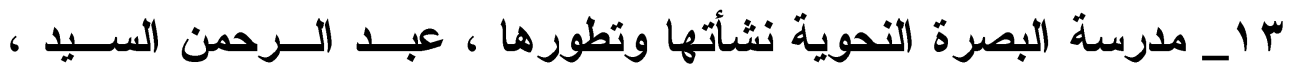
الطبعة الأولى، توزيع دار المعارف بمصر . لبهرة

ع ا_معجم الأدباء ، تصنيف :ياقوت الحموي ، دار الكتب العلمية ، الطبعـة الثانية ، لبنان.

1 ـــمع الهوامع في شرح جمع الجوامع ، تأليف: الســيوطي، تحقيـق:

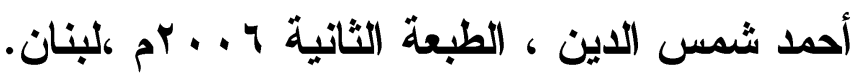




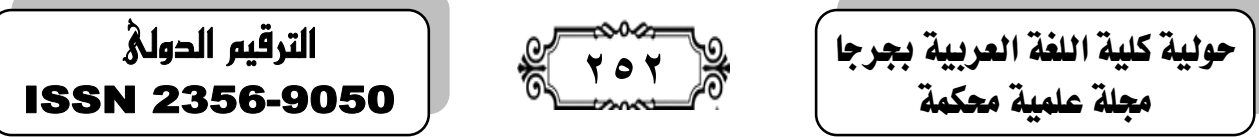

فهرس الإوضروعات

\begin{tabular}{|c|c|c|}
\hline |لمفهة & 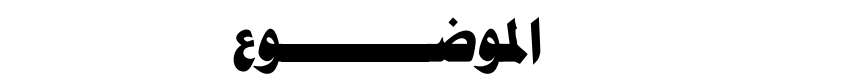 & $\hat{P}$ \\
\hline Mr & هلخص البحث & 1 \\
\hline$r Y \varepsilon$ & Research Summary & r \\
\hline rro & * هقدمة : مقدة & $\mu$ \\
\hline rYY & الفصل الأول : السـماع & $\varepsilon$ \\
\hline rYY & السماع عند البصريين: & 0 \\
\hline re. & السمثاع عند الكوفيـين & 7 \\
\hline ו & ثانيًا القياس: & $v$ \\
\hline rrt & القياس عند البصريين & $\Lambda$ \\
\hline E & القياس عند الكوفيسين : & 9 \\
\hline ס r p & ثالثًا: استصحاب المال: & 1. \\
\hline rrv & رابهًا: القواعد المشتزكة بين البصريسن والكمفيسن & 11 \\
\hline$r \leqslant q$ & "خـاتمة : & ir \\
\hline ro. & " المادر والمراجع : & ir \\
\hline ror & فهرس الموضوعات & $1 \varepsilon$ \\
\hline
\end{tabular}

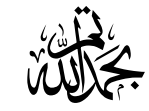

